Canadian Journal of Family and Youth, 6(1), 2014, pp 89-113

ISSN 1718-9748 () University of Alberta

http://ejournals.library.ualberta.ca/index/php/cjfy

\title{
Lighting Diyas: \\ Paving Paths for the Tigress Within
}

\author{
Jinny Menon
}

\begin{abstract}
This paper explores the author's contention that South Asian females are raised within a familial culture which may serve to devalue them and in addition, can potentially bring them into conflict with dominant school narratives. As such, South Asian female students learning in Canada require alternative stories, "counterstories," (Lindemann Nelson, 1995) and/or counter-narratives on which to construct their identities. In attempting to respond to the question as to how IndoCanadian female students can negotiate their "stories to live by," (Clandinin \& Connelly, 2000) those complex narratives dealing with ethnicity, culture, family, school, and identity, the author puts forward the premise that children's literature can lead to a positive response. Selected children's literature are surveyed as a possible means of cultivating strong cross-cultural connections amongst students, parents, and teachers, and assisting Indo-Canadian girls in primary and secondary grades to succeed as healthy individuals. Woven throughout the paper are brief fragments of a story which the author wrote and chose to include as a way of employing a metaphorical device.
\end{abstract}

Jinny Menon is a professional educator currently enrolled in a doctoral program at the University of Alberta in the area of Teacher Education in the Department of Elementary Education. It is her aspiration to gain a deeper understanding of how to conduct, report, and publish ethical research through a narrative inquiry lens. Her educational, working, and volunteer experiences have served to inform her recent research interests in intercultural competence and how Indo-Canadian female students are currently negotiating their identities both on and off school landscapes. It is her hope that inquiring into such stories will contribute to an existing knowledge base and provide opportunities for change and growth. 
Menon

\section{East Meets West}

“What are you... a Paki or something?" While I recall the older boy's question, and I remember the genuine curiosity which laced his voice, I can't remember how I responded. I do remember thinking what is a Paki and what did he mean by asking me that. We continued to walk across the green field together, my hands tucked into the side pockets of my hot pink sateen jacket which was too thin for the early spring weather and him tugging his bike over the slick wet grass as we made our way to school. Elementary had been a time of great highs and lows-my first time snowshoeing, my first time sledding, my first time being told to go back where I came from, my first time being confronted (by my Grade Six teacher no less) with the question, how had it felt to live among the elephants? I soon came to understand being born in Canada was not enough to call oneself Canadian and if you had 'muddy' skin then the situation became infinitely more complex. Life at home was fraught with danger of another kind. Good daughters were expected to listen to their fathers without talking back, to speak when spoken to, and above all else behave with decorum - all conditions which I failed to meet. With my cousins moving away to another part of town, I felt even more isolated with my brown complexion and brown eyes. Experiencing tensions at home and at school, I turned to books to seek solace. I secreted myself between library shelves that nobody else seemed to go to and chose books that appeared unique and ancient. I imagined myself as an archeologist of sorts excavating stories which I deemed abandoned. Simultaneously, I searched out those paperbacks decorated with glossy, eye-catching covers. These were the stories which had been deemed by my friends as worthwhile reading and by my teachers as appropriate grade level reading material. I found myself jostling for first place to solve the mysteries three young detectives undertook, worrying about a certain pair of blonde twins who were as different as night and day, learning how séances could be conducted, scaring 
myself silly with a girl haunted by an evil spirit, envying another girl blessed by her grandmother with a special gift, panicking over students plotting to kidnap their teacher, and even travelling back in time with an orphaned girl. I enjoyed these stories but felt as if something were missing. It would be later that I would realize that while my formative years were dominated by a love of stories, I had been engaging in a quest to find narratives which captured the realities I knew, the cultural understandings which shaped second generation South Asian females. None of the characters I had read about seemed to reflect my experiences as an Indo-Canadian. Again, it would be only much later, in fact, years into my own teaching career that I would finally be able to pause and catch my breath having found stories which reflected and ascribed value to the cultural heritage I embodied; the experiences I had lived and continued to live as an Indian female struggling to live her life in Canada, as a Canadian female attempting to live her life as an Indian, and as an Indo-Canadian educator striving to better the lives of her diverse students by sharing her love of and for story.

I introduce the above autobiographical account as a means of segueing into a discussion whose primary aims are multifold. First, it is my contention that South Asian females are raised in a familial culture which may serve to devalue them and additionally, can potentially bring them into conflict with dominant school narratives. Secondly, South Asian female students in primary and secondary classrooms learning in Canadian schools require "counterstories," (Lindemann Nelson, 1995) and/or counternarratives on which to construct their identities. Lindemann Nelson (1995) suggests when these narratives make their way into "chosen communities, they permit their tellers to re-enter, as full citizens, the communities of place whose goods have been only imperfectly available to its marginalized members" (p. 5). The question arises how can the "hyphenated Canadian" (Shariff, 2008) or Indo-Canadian female 
student negotiate her "stories to live by," (Clandinin \& Connelly, 2000) those complex narratives dealing with ethnicity, culture, family, school, and identity? As a possible means of achieving this lofty goal I suggest that children's literature which: seeks to explore the liminal space of identity, features strong South Asian female role models, and/or depicts situations which permit for a positive outlook on Indian culture may do this. Recognizing there is no one Indian girl and that there is heterogeneity to be found even within homogeneity, I will employ Superle's (2011) descriptions for certain terms. I will use the terms: Indian, Indo-Canadian, and South Asian interchangeably to refer to those individuals who reside in Canada and are ethnically identifiable as Indian "through at least one parent" and will also, borrow her definition of bicultural identity to refer to both fictional and actual diasporic characters/people who view "themselves as simultaneously Indian, British, American, or Canadian” (p. 5). Throughout my discussion I will endeavor to explain why I chose the books I did and attempt to outline potential benefits and/or drawbacks for using them in the elementary and/or secondary classroom. Likewise Wiltse (2005) reminds us, "Not only do school and classroom practices determine who students can be and what students can learn in current settings, but they also play a role in who they will become and what they will learn in subsequent settings" (p. 250).

\section{Caging the Tigress: Cultural Narratives}

It is beyond the scope and intent of this paper to delve deeply into issues pertaining to the devaluing of South Asian women. Instead, I will briefly touch upon a few cultural threads which I see as pertinent to the discussion at hand. Javaid, Jabeen and Omer (2012) in a review of Indian school textbooks found depictions of males and females overwhelmingly reflected constructs of patriarchy. In her analysis regarding the status of Indian women and language, Devi (2003) examined common Indian proverbs and ascertained females were: construed as objects to 
possess, having no worth on their own, possessing worth only in relation to a male, and lacking intelligence. Years earlier, Guzder and Krishna (1991) commented, "While the relationship of families and individuals to tradition is not rigid or stereotyped, the identity and assimilation of Indian women is still framed by traditional family and cultural paradigms that both idealize the mythic feminine-maternal and devalue women" (p. 257). In exploring the identity of women in different Indian myths, these authors argued that Indian women living within Western countries bump up against internalized cultural mythologies which continue to influence their identities. Recent research appears to echo similar findings suggesting an unsettling continuity in how Indian females might view themselves and how they can possibly be viewed by others. Gill and Mitra-Kahn (2009) presented a number of underlying cultural determinants (religion, kinship, education, employment, and dowry) for the preference against daughters and for sons and distressingly concluded, "Ex South Asian communities in the UK have found alternative ways to perpetuate traditional cultural values and norms; instead of acting to lessen the chances of survival for daughters after they are born" (p. 697). These researchers cite how popular magazines and media exported out of India and into North America and the UK often replicate scenarios 'back home.' In Canada, Handa (2003) interviewed young South Asian teenage girls and found their constructed identities revolved around themes of inclusion and exclusion. Depression, suicide, and isolation were commonly disclosed feelings amongst her participants. The community health nurses consulted in this study corroborated these experiences citing "a disturbing increase of depression, eating disorders, alcoholism, and suicide attempts among young South Asian women in Toronto" (Handa, 2003, p. 30). Given this, questions about what can be done to mitigate and/or ameliorate the ways in which some South Asian girls deal with issues of identity need to be asked. These are not novel queries for the time and context we live 
in. Khosla (1980) remarked of South Asian Canadian young women, "Education appears to be of pivotal importance not only because it enables the woman to become more economically independent but because through it she acquires the self-confidence necessary to affirm herself as an individual" (p. 129). More recently, Mehta (2009) observed because there has been an increase in the number of South Asian women entering the workforce, there is a corresponding need for additional research to be conducted to discern how educational attainment influences financial independence and self-sufficiency. Insofar as female Indo-Canadian students are concerned, it is important to consider how these often hushed narratives may influence identity and what role South Asian children's literature in the classroom can play in disrupting these harmful narratives. It is to these points that I turn to next.

She paced back and forth and still they prodded her with the stick. The sound which emerged from deep within her throat came out as whimper. It was a mewling cry in the oppressive velvet of the night. They laughed at that and her eyes glinted and this time when she opened her jaws, she let them behold the sharp white of her teeth as she roared her anger.

\section{Unleashing the Tigress: Intersections Between Schools and Stories}

Ragoonaden (2010) intimates teachers are often uninformed that for many visible minority students, identity and cultural background are inherently multifaceted issues defying simple understandings. With South Asians having become the country's largest visible minority group (Statistics Canada, 2010), it is critical that elementary educators recognize female students of this demographic may arrive in the classroom embodying complex notions of culture and identity which in turn will shape their "stories to live by" (Clandinin and Connelly, 2000) on school landscapes. Adopting a more optimistic tone than Ragoonaden, Johnston (2010) contends this change in demographics has "encouraged an increasing number of English language arts teachers to re-evaluate the status of the established canon of novels they have been teaching and 
to consider the potential of novels that value stories and experiences outside the Western mainstream perspective" (p. 134). If we accept that both Ragoonaden and Johnston are correct, that teachers may be misinformed about the experiences of their diverse students and concurrently, teachers are seeking ways to foster intercultural competence, positive self-esteem, and an awareness that people cannot be reduced to "a single story," (Adichie, 2009) then it follows that teachers by virtue of their status can create change. It also becomes rapidly apparent that we are operating on the understanding that books in and of themselves do not contain meaning but that readers interact or "transact" (Rosenblatt, 1994) with books to produce meaning. Like Bruner (2004), I concur "that the mimesis between life so-called and narrative is a two-way affair" (p. 692). This is a powerful idea for it implicates various sites for possibility. Galda and Beach (2001) propose literature can provide windows and mirrors through which we can see the stories of our lives in the forms of text worlds and lived worlds. However, what happens when one peers through a window or looks at a mirror only to find blurry or false images which ascribe value to hegemonic reflections and little or none to marginalized groups? Hefflin and Barksdale-Ladd (2001) reflect, "To read for years and not encounter stories that connect closely with one's own cultural understandings and life experiences is problematic" and further elucidate, "When children read books that are interesting and meaningful to them, they can find support for the process of defining themselves as individuals and understanding their developing roles within their families and communities" (p. 810).

All she wanted to do was leave this unnatural place. She belonged out there in the world, not in here... never in here. She was not meant to be tamed or domesticated. They had left her in peace for now but it had come at a cost. She was bruised and battered wanting to lick her wounds in private. She flicked her tail and froze. Something had changed. 
Menon

\section{Bridging East and West}

Tales for the Tigress: Aspirational Stories in Picture Books and Novels

Rosenblatt (1994) delineates between "critics and literary theorists" (p. ix). The first group subscribe to the view that there is an absolute truth which is to be found within the text. In a historical sense, "literary work, viewed as embodying the personality and life of the author, came often to be treated mainly as a document in the biography and times of the author, or as a document in the history of literary movements" (p. 2). Members in the second camp situate themselves in opposition to the former stance by attributing great import to the personality of the reader and "see the text as empty, awaiting the content brought by the reader" (p. 4). Rosenblatt proffers a more moderating position. Eschewing a dualistic approach, she draws upon Dewey's notion of transaction (p. xiv) and instead affords credence to the idea that the reader transacts with the text in a two-way relationship. For her, "the finding of meanings involves both the author's text and what the reader brings to it" (p. 14). This dialogue accentuates the difficultly in determining which books can best shape literary events so to disrupt cultural and individual narratives of devaluation of Indo-Canadian girls while assisting them in navigating their bicultural experiences. Exacerbating the situation is the seeming lack of interest for children's books featuring South Asian characters in certain circles.

Superle (2011) surveyed 101 children's books written in English depicting Indian childhood in some manner. The books were published between 1988 and 2008. They were authored by those living in India, the United Kingdom, and North America. From her extensive research she surmises, "Indian or South Asian texts are rarely mentioned in many bibliographies of multicultural children's literature" (p. 35). What is more, unlike the genesis of contemporary English-language children's literature in India which emerged from "ancient Sanskrit narratives, 
a well-established oral tradition, and post-Independence national aspirations" (p. 36) aimed at a very specific audience of middle to upper class English speaking children residing in urban areas, diaspora children's literature did not follow this route. In fact, Superle proposes it was the evolution of multicultural children's literature which permitted the birth of Indian texts outside of India. She further provocatively asserts, "The small minority of authors that produces these texts is part of a parallel culture that must wrest space from the dominant culture in order to be heard" and have the additional challenge of writing to appeal to "children from the Indian diaspora and those from many other cultures" (p. 36).

One way in which these authors meet these challenges can be found in how they mould their girl characters so that they can act as foils to cultural narratives with messages of girl devaluation. Lindemann Nelson (1995) defines a counterstory as "a story that contributes to the moral self-definition of its teller by undermining a dominant story, undoing it and retelling it in such a way as to invite new interpretations and conclusions" (p. 23). Alongside this construct of the counterstory or counternarrative, she employs the term "fragment of fiction" to connote "fiction that says something true about actual possibilities and practices" (p. 25). It is with these two notions foregrounded, I will speak to several picture books and novels which I propose exemplify these aspirational ideals often through a masala ${ }^{1}$ of themes such as identity, culture, and girlhood.

Novels

Canadian writer, Rachna Gilmore's (2001) Group of One features the fifteen year old protagonist Tara, one of three daughters born of Indian immigrants living in Canada. As an IndoCanadian she is appalled when her teacher singles her out to ask her what her heritage is and then proceeds to chastise her, "Pity, you don't know your language" (p. 4). When Tara's grandmother

${ }^{1}$ Masala refers to a blending of spices to produce an often pleasing combination of flavours. 
comes from India to visit the family in Ottawa, an inevitable clash of culture ensues and Tara finds herself struggling to understand why her grandmother is the way she is even as she negotiates the tensions of her own bicultural identity. Additionally, Gilmore repudiates a black and white rendering of the other Indian female characters in the story. Grandmother Nanji, readers discover, was a rebel in the 1942 Quit India movement. Tara's mother is portrayed as a fierce female who is willing to go to battle when she perceives an injustice being perpetuated against her daughter. While Gilmore's narration can be construed along lines of a story depicting so-called Indian issues, she defies this overly simplistic classification by writing for a diverse audience. Readers are invited to transact with the text in different ways. For instance, the themes of family, sibling rivalry, young love, school, stereotyping, and personal growth will appeal to young readers of various backgrounds.

Tanuja Desai Hidier (2002) chooses a different kind of central character altogether in her young adult novel, Born Confused. In contrast to Tara, Dimple does not straddle her worlds as successfully. Here we have a protagonist who appears to negate her Indian culture in favour of the more dominant American culture as captured in the following passage encountered early on in the text: "Gwyn appeared the very image of the American Dream itself, the blonde-rooted, blonde-haired, blue-eyed Marilyn for the skinny generation. And if I was her reverse twin-the negative to her positive-that made me? The Indian nightmare? The American scream?” (p. 10). Dimple unlike Tara does not have a positive self-image. It is only after several interactions with extended family members and encounters with her friends that she awakens to seeing herself differently. This shift from "seeing Indianess as alien and inferior" (Superle, 2011, p. 143) to identifying with both Indian and Western culture could be indicative of a utopic scenario where an equal balance is achieved by the main character. On the other hand, Dimple's resistance to be 
cast as a 'good Indian girl' situates her character as one who is more plausible to the reader for her resistance is not constant but rather ebbs and flows with her experiences.

Yang (2008) draws our attention to the role the graphic novel can play in the classroom. He delineates several benefits whereby graphic novels bridge the gap between image and text when "image and text share narrative responsibility" (p. 187) and the rate of information-transfer is placed in the reader's control. Keshni Kashyap's (2011) graphic novel, Tina's Mouth: An Existential Comic Diary encompass these very traits. I suggest this book like the other two young adult novels discussed earlier falls within the category of an aspirational counternarrative. The main character is spunky fifteen year old Tina Malhotra who explores questions of identity in often humorous ways. At one point Tina wryly comments, "My grandmother used to tell me about the caste system in India and once I even did a presentation about it. Everyone thought it was totally barbaric, but high school is no different" (p. 35). Tasked with an assignment in her English Honours elective in existential philosophy to determine who she is and who she is becoming, Tina chooses to maintain a diary. With entries written to the philosopher Jean-Paul Sartre, readers accompany Tina as she lives her life as a student at Yarborough Academy while concomitantly dealing with the ups and downs of being a member of a Southern Californian intellectual Indian family.

Neela, at eleven years old is the youngest heroine of the novels I have highlighted thus far. She plays the veena (a traditional Indian instrument) and has dreams of being a famous musician. The instrument, a gift from her grandmother, has a history of vanishing. Consequently, when Neela's treasured veena goes missing, the young girl is quite upset. As a set of clues emerge which point to India, Neela is left wondering even if she manages to locate her instrument, how can she prevent it from disappearing again. Sheela Chari (2011) refrains from 
taking a heavy handed approach to her novel, Vanished and "integrates questions of race and culture unselfconsciously into the story" (Johnston, 2010, p.150). Themes of an Indian nature along with others such as music, friendship, love, and mystery situate this book as a book which can be used to promulgate a healthy and well balanced depiction of Indian girlhood. The trials and tribulations Neela faces evoke the possibility that Indian girls have agency to forge their own identities in ways which are meaningful to them. At the same time, readers are afforded a compelling mystery to unravel. Neela routinely adopts the role of a spy in the book. At one point in the story she and her sidekick, Matt venture onto a public bus. They follow a fellow classmate whom Neela suspects of having something to do with the disappearance of her veena. Readers are made privy to Neela's excitement in the following passage: "She felt a thrill pass through her. I am on an adventure. The thought made her tingle all over" (p. 158). Intended for a younger audience than the previous novels showcased, Neela makes for a likable and believable protagonist.

\section{Picture Books}

What about the younger reader? Can young female Indian girls find picture books which serve to uplift rather than demote, to empower rather than harm, to cherish rather than devalue their identities? Jobe (2003) reflects:

Realistic picture books allow us to see our own culture, recognize our own heritage and experience the culture of others. All children should have the right to see themselves reflected in the books they read. Such imaging is crucial for developing a positive selfconcept and a sense of who we are as Canadians. Picture books help children to establish their cultural identity. It becomes increasingly important to identify and share those Canadian picture books which give a visual representation of our culture, what is in the past and what is today. Canadian children must have the opportunity to see themselves in the picture books they experience (p. 80).

Much to my astonishment I was able to find picture books which I felt could possibly uplift, empower, and cherish young Indian girls. It is of interest that some of these books I unearthed 
could be found only after plugging in the words East Indian, a dismayingly pejorative term possessing colonial connotations for some, into online library and book sites. Kashmira Sheth's (2007) My Dadima Wears a Sari and Pooja Makhijani’s (2007) Mama's Saris as the two titles indicate, offer stories which centre about saris. ${ }^{2}$ Both books feature gorgeous illustrations which beg the eye to pause and linger. While the first pays homage to Indian grandmothers and the other honours Indian mothers, both books capture and spotlight the love that can be had between family members. In contrast, Little Pria's Big Canadian Adventure by Canadian author Tin-An Chen (2004) does not provide as convincing a portrayal of bridging worlds highlighting the difficulty of ascertaining authenticity in stories (Johnston, 2010). Yet this story is included in this discussion despite its somewhat simplistic treatment of the Indian/Canadian immigration experience because it can be used as a vehicle for dialogue about such experiences. Young readers will no doubt appreciate the souvenir goose that is magically and mysteriously brought to life. The goose takes Pria on a flying tour where she can learn about what it means to be Canadian. Used in the classroom, it should ideally be followed up by a book such as Gilmore's (1994) Lights for Gita. In this book little Gita faces the fact that while celebrating Diwali ${ }^{3}$ in Canada during a blizzard is not the same as celebrating the holiday in India, it can be enjoyable. In my own Grade 2 and 3 classes this book has proven to be a meaningful way of engaging talk amongst children about traditions.

The remaining three books I wish to touch upon are written by the same author. In Krishnaswami's (2006b) The Closet Ghosts, Anu is confronted by ghosts in the closets of her new home. Charmingly rendered illustrations bring Anu's angst to life and vividly capture her

\footnotetext{
${ }^{2}$ Saris are traditional Indian garments consisting of long swaths of fabric which can be wrapped in numerous ways around women's bodies.

${ }^{3}$ Diwali is known as the Festival of Lights. It is a holiday celebrated by Hindus all over the world. The festival is marked by the lighting of candles and oil lamps, the exchange of gifts and sweets, and is held to honour the triumph of good over evil as unfolded in the Hindu epic, The Ramayana.
} 
Menon

experience as a newcomer to America. Recently arrived immigrant children will be able to draw parallels to their experiences. By positioning the Hindu monkey god, Hanuman as an ally to the young female protagonist, Krishnaswami capitalizes on the popularity of the trickster god and intelligently offers a new way of imagining cultural myths. In Uma Krishnaswami’s (2005) proffering, The Happiest Tree: A Yoga Story, Meena, a clumsy girl who fears her role as a tree in the upcoming Red Riding Hood class play, learns how to handle her worries in a safe manner. During a visit to a local Indian grocery store Meena hears about a children's yoga class and with the encouragement of her family and family friends joins the class. Meena discovers she can achieve peace within herself. Once again, Krishnaswami successfully fleshes out her main character and in doing so provides a story which not only Indian girls can relate to but those of diverse backgrounds can value as well. Bringing Asha Home (Krishnaswami, 2006a) made its way into this discussion not because it features a strong Indian girl character but because the story instead portrays a caring young Indian boy. Arun very much wants a sister. He is delighted because his parents are in the process of adopting a little girl from India who they wish to bring to their home in America. In having her characters act in this manner, Krishnaswami cleverly ascribes value to the process of adopting an Indian girl. Looking across all three books, she expertly interweaves stories of culture, identity, and girlhood within larger narratives.

A low reverberating growl emerged from her throat before she could silence it. She prowled silently forward even as the evening breeze brought the scent of perfumed jasmine to her nostrils. Her ears twitched and she paused, excitement growing within her. The door to her cage was standing slightly ajar...

\section{Catch a Tigress by Her Tale: Some Caveats}

Bainbridge and Fayjean (2000) articulate, "It is important that Canadian children read books that are created by Canadian authors and illustrators; books that derive from the culture to 
which the children belong” (p. 55). More recently, Bainbridge, Carbonaro, and Green (2005) shared, "We believe that Canadian books, in addition to books from around the world, play an important role in helping students understand who they are in relation to each other" (p. 312). In being exposed to a variety of quality children's literature, children are given the opportunity to don the metaphorical shoes of another so to, as Lugones (1987) writes, travel to different worlds. Bainbridge, Oberg, and Carbonaro (2005) assert, “One specific ideological stance found in children's literature, no matter from what nation it derives, is that of national identity" (p. 2). Handa (2003) wrote earlier, "Young South Asians struggle to fashion an identity that speaks to their experience of being South Asian in Canada. In so doing, they often unsettle and resist certain mainstream definitions of both South Asian and Canadian" (p. 5). Laying these two contentions alongside one another, the case can be made that it is increasingly important that we as educators proffer books which provide authentic representations which our students can relate to and simultaneously enjoy. At the same time we need to be cognizant that because of the numerous worlds we inhabit, teachers and students have more than one narrative to share and that these narratives may require a willingness to be dispositioned. Vinz (1997) suggests this occurs when we open ourselves up to ambiguity and uncertainty in order to shape new understandings. Gergen (2004) reminds us, "While the right stories can create satisfying lives, so too the absence of good stories can have the opposite effect" (p. 6) and insightfully remarks, "Such missing stories could have vital potential for changing the lives of girls" (p. 7). Teachers' discretionary authority is such that they can act as gatekeepers either permitting for certain books to be introduced into the classroom or blocking them from entering the classroom culture (Davila \& Patrick, 2010). So while it is possible for teachers' understanding of pedagogy and praxis for their students to be informed by children's literature, it is in some manner up to them to decide 
what role (if any) they would like contemporary English-language Indian children's literature to play in their classrooms. It is worthwhile to note that while I was happily able to find such books, it was challenging. Books featuring Indian characters let alone Indo-Canadian characters were scarce. Similarly, books featuring Canadian authors writing about Indian children were not abundantly available.

Speaking to the idea that characters in Indian diasporic children's literature are often depicted as "experiencing mild to severe emotional trauma" while navigating tensions of identity, Superle (2011) is quick to point out, "It is possible that several texts manipulate or perpetuate stereotypes of cultural identity as a source of trauma in attempt to provide stimulating narrative conflict" (p. 134). Her contention could be problematic on two fronts. First, in making this argument is Superle saying then that cultural identity cannot be a source of distress? Second, it appears that she is neglecting to recognize that all authors, not simply those of diasporic children's literature, deliberately employ literary devices in ways in which to convey messages explicitly or implicitly. What is germane to this discussion is the recognition that children's literature can be construed in numerous ways. Sims-Bishop's (as cited in Hill, 2011) categorization of children's multicultural literature was helpful in determining possibilities for how each of the books presented in this paper could be used in the classroom (see Appendix).

Early in her book, Superle (2011) poses the difficult questions, "Who can successfully negotiate bicultural identity? Which girls can achieve gender equality?" and then responds to her own queries by noting, "It is primarily urban, middle-class child characters who succeed in achieving these goals, which are positioned textually as positive outcomes" (p. 4). She further observes, "In their tendency to default to optimistic endings, Indian children's authors stand apart from well-established South Asian writers who produce English language novels for an 
adult audience" (p. 9). Taken separately, these claims speak to a desire for additional quality literature which portray girl characters other than middle-class urbanites and endings which are not necessarily optimistic. Even so, it is promising (irrespective of socioeconomic status) that South Asian girls are being written about in favourable terms. Moreover, those Indian children's authors who "want to imagine hopeful scenarios which improve upon reality" (p. 7) are addressing a need for aspirational stories. While they may not receive the same type of recognition as their colleagues who write for an adult audience, they are providing counterstories to the cultural narratives many South Asian girls face. To my way of thinking these authors are the unsung heroes/heroines who make possible what might hitherto seem unimaginable.

The door had not been opened before. Someone had either forgotten to lock it or she thought with no little astonishment, someone had chosen not to lock it. It was a fine distinction but one she could appreciate. Soon they would approach. She did not know who her benefactor was but it mattered not because she was already racing, her wounds forgotten as she burst past the bars and onto the packed earth.

\section{Tygress! Tygress! Burning Bright ${ }^{4}$}

Shariff (2008) opines, “South Asians become 'othered' by a dominant culture which categorizes them as 'visible minorities,' 'ethnics,' 'immigrants,' or 'foreigners.' These categories are considered to be incommensurable with being a 'real' Canadian despite the promises of multiculturalism" (p. 72). Expressing a similar sentiment, Handa (2003) employs the metaphor of the tourist for second-generation South Asians and posits they "are always in a state of just visiting, neither here nor there, neither quite in Canada nor back home" (p. 14). In addition to adopting an analogous perspective, I began this paper with the claim that harmful stories were being woven perhaps subversively into the larger narratives of young girls' lives. As well, I noted that even when living in Canada, South Asian girls could be bound by these cultural tales

${ }^{4}$ Drawing on my metaphor of the tigress as an indomitable spirit I pay homage to William Blake's well-recognized and beloved poem, The Tyger. 
of tragedy. In contemplating how this lexicon of misogyny may write and then imprint itself on the lived and told stories (Clandinin \& Connelly, 2000) of South Asian girls, I chose to speak about children's literature which can act as counternarratives to alter the plotlines of these girls' lives and in turn, provide them with different stories to imagine. Sarbin (2004) clarifies, "Imagining connotes an active process, something the imaginer does" (p. 6) whereby "the act of reading or listening to a story, in the context in which the reader's moral constructions are engaged, produces embodied self-perceptions" (p. 16). The implications are profound especially with respect to how educators working alongside their students can facilitate such connections between story and identity work. Noddings (2005) maintains that caring in "relations provide the foundation for successful pedagogical activity" (para. 11). In imagining a new curriculum as lived (Aoki, 1993) through children's literature, educators can help students enter into meaningful dialogue by communally creating safe spaces within classroom communities (Orr, 2005). Through opening up such spaces, the negotiating of identities can be construed as favourable endeavours by parents, students, and teachers. Children's literature can act as catalyst for imagining new worlds of possibilities. The books discussed in this paper are not meant to be an exhaustive list but are rather intended to serve as possible points of disruption. These counterstories I suggest, constitute the diyas ${ }^{5}$ which can help to pave the paths for the selfempowerment of Indian girls. I want to imagine then in the most active sense of the word, a new world for young South Asian girls needing narratives bespeaking of promise and hope, a different world for those students whose stories echo with refrains of pain and shame, and a reimagined world for educators like myself who are just beginning to understand how identity is to be found and shaped in the stories we live and share, the tales we rework and retell, and in the narratives we listen to and embody.

${ }^{5}$ Diyas are oil lamps composed of a shallow clay pot and a cotton wick. 


\section{Lighting Diyas}

The strange flickering flames should have frightened her. Fire could burn and singe her coveted fur but for some reason they seemed to urge her onwards even as the welcoming heat began to warm the chill from her bones. The earth felt good and right beneath her paws and she took a deep breath and leaped... 
Menon

\section{Appendix 1:}

\section{Contemporary English-Language Indian Children's Literature Used in this Paper Organized According to Sims-Bishop's Typology of Multicultural Literature (as cited in Hill, 2011)}

\section{Key:}

Melting Pot Books: indicative of a fusion/cultural assimilation theme

Socially Conscious Books: highlights unique experiences of a cultural group

Culturally Conscious Books: an authentic voice is used to depict certain groups' experiences

\begin{tabular}{|l|l|l|}
\hline \multicolumn{1}{|c|}{ Picture Book Title } & \multicolumn{1}{c|}{ Author } & \multicolumn{1}{c|}{ Typology } \\
\hline $\begin{array}{l}\text { Little Pria's Big Canadian } \\
\text { Adventure }\end{array}$ & Tin-An Chen (2004) & Melting Pot Book \\
\hline Lights for Gita & Rachna Gilmore (1994) & Culturally Conscious Book \\
\hline The Happiest Tree: A Yoga Story & Uma Krishnaswami (2005) & Culturally Conscious Book \\
\hline Bringing Asha Home & Uma Krishnaswami (2006a) & Culturally Conscious Book \\
\hline The Closet Ghosts & Uma Krishnaswami (2006b) & Culturally Conscious Book \\
\hline Mama's Saris & Pooja Makhijani (2007) & Culturally Conscious Book \\
\hline My Dadima Wears a Sari & Kashmira Sheth (2007) & Typology \\
\hline \multicolumn{1}{|c|}{ Novel Title } & Culturally Conscious Book \\
\hline Vanished & Sheela Chari (2011) & Culturally Conscious Book \\
\hline A Group of One & Rachna Gilmore (2001) & $\begin{array}{l}\text { Socially Conscious } \\
\text { Book/Culturally Conscious Book }\end{array}$ \\
\hline Born Confused & Tanuja Desai Hidier (2002) & Culturally Conscious Book \\
\hline Tina's Mouth & Keshni Kashyap (2011) & \\
\hline
\end{tabular}




\section{Contemporary English-Language Indian Children's Literature Cited in This Paper}

Chari, S. (2011). Vanished. New York, NY: Disney Hyperion Books.

Chen, T. (2004). Little Pria's big Canadian adventure. (A. Hodge, Illus.). Mississauga, ON: Cornucopia Books.

Gilmore, R. (1994). Lights for Gita. (A. Priestly, Illus.). Toronto, ON: Second Story Press.

Gilmore, R. (2001). A group of one. Markham, ON: Fitzhenry \& Whiteside.

Hidier, T. D. (2002). Born confused. New York, NY: Scholastic Press.

Kashyap, K. (2011). Tina's mouth: An existential comic diary. New York, NY: Houghton Miffin Harcourt Publishing Company.

Krishnaswami, U. (2005). The happiest tree: A yoga story. (R. Jeyaveeran, Illus.). New York, $\quad$ NY: Lee \& Low Books Inc.

Krishnaswami, U. (2006a). Bringing Asha home. (R. Jeyaveeran, Illus.). New York, NY: Lee \& Low Books Inc.

Krishnaswami, U. (2006b). The closet ghosts. (S. Bhabha, Illus.). San Francisco, California: Children's Book Press.

Makhijani, P. (2007). Mama's saris. (E. Gomez, Illus.). New York, NY: Little, Brown and Company.

Sheth, K. (2007). My dadima wears a sari. (Y. Jaeggi, Illus.). Atlanta, Georgia: Peachtree Publishers. 
Menon

\section{References}

Adichie, C. (2009, July). The danger of a single story. Retrieved from http://www.ted.com/talks/ chimamanda_adichie_the_danger_of_a_single_story.html

Aoki, T. T. (1993). Legitimating lived curriculum: Toward a curricular landscape of multiplicity. Journal of Curriculum and Supervision, 8(3), 255-268. Retrieved from http://web.ebscohost.com.login. ezproxy.library.ualberta.ca/ehost/pdfviewer/pdfviewer?sid=adb158c6-6936-4cc5-8d30 e928b6487ced\%40sessionmgr13\&vid=4\&hid=10

Bainbridge, J., \& Fayjean, J. (2000). Seeing oneself in a book: The changing face of Canadian children's literature. English Quarterly, 32(1), 55-62. Retrieved from http://login.ezproxy.library.ualberta. ca/login?url=http://search.proquest.com/docvi ew/233 297089?accountid=14474

Bainbridge, J., Carbonaro, M. \& Green, N. (2005). Canadian children's literature: An Alberta survey. Alberta Journal of Educational Research, 51(4), 311-327. Retrieved from http://login. ezproxy.library.ualberta.ca/login?url=http://search.proquest.com/docview/228592829?accountid= 14474

Bainbridge, J., Oberg, D. \& Carbonaro, M. (2005). "No text is innocent”: Canadian children's books in the classroom. The Journal of Teaching and Learning, 3(2), 1-14. Retrieved from http://login.ezproxy.library.ualberta.ca/login?url=http://ojs.uwindsor.ca /ojs/leddy/ index.php/JTL/article/view/98/132

Bruner, J. (2004). Life as narrative. Social Research, 71(3), 691-709. Retrieved from http://login.ezproxy.library.ualberta.ca/login?url=http://search.ebscohost.com/login.aspx? direct=true \&db=a9h\&AN=14829619\&site=ehost-live \&scope=site

Clandinin, J. D., \& Connelly, M. F. (2000). Narrative inquiry. San Francisco, CA: Jossey-Bass. 


\section{Lighting Diyas}

Davila, D. \& Patrick, L. (2010). Asking the experts: What children have to say about their reading preferences. Language Arts, 87(3), 199-210. Retrieved from http://ezproxy.library.ualberta.ca/ login?url=http://search.proquest.com/docview/196864233/13B1B02E555775A4053/6?accountid $=14474$

Devi, B. (2003). Women in the mirror of Indian languages. Languages in India, 3(1). Retrieved from http://www.languageinindia.com/jan2003/womeninindianlanguages.html

Galda, L., \& Beach, R. (2001). Response to literature as a cultural activity. Reading Research Quarterly, 36(1), 64-78. doi:10.1598/RRQ.36.1.4

Gergen, M. (2004). Once upon a time. A narratologist's tale. In C. Daiute \& C. Lightfoot (Eds.), Narrative analysis: Studying the development of individuals in society (pp. 267-285). Thousand Oaks, CA: Sage. Retrieved from http://login.ezproxy.library.ualberta.ca/login?url=http:// www.library.ualberta.ca/permalink/opac/5491403/WUAARCHIVE

Gill, A. \& Mitra-Khan. (2009). Explaining daughter devaluation and the issue of missing women in South Asia and the UK. Current Sociology, 57(5), 684-703. doi:10.1177/0011392109337652

Guzder, J. \& Krishna, M. (1991). Sita-Shakti: Cultural paradigms for Indian women. Transcultural Psychiatry Review, 28, 257-301. doi:10.1177/136346159102800401

Handa, A. (2003). Of silk saris and mini-skirts: South Asian girls walk the tightrope of culture. Toronto, ON: Women's Press.

Hefflin, B. R., \& Barksdale-Ladd, M. (2001). African American children's literature that helps students find themselves: Selection guidelines for grades K-3. The Reading Teacher, 54(8), 810-819. Retrieved from http://login.ezproxy.library.ualberta.ca/login?url=http:// search.proquest.com/docview/203276198?accountid=14474

Hill, R. A. (2011). The color of authenticity in multicultural children's literature, VOYA, 12(2), 445-447. Retrieved from http://www.debbydahledwardson.com/files/The_Color_ of_Authenticity.pdf 
Menon

Javaid, U., Jabeen, S., \& Omer, S. (2012). Rife manifestations of gender segregation in Indian society: Evidence from textbooks. A Research Journal of South Asian Studies, 27(1), 21- 34. Retrieved from http://pu.edu.pk/images/journal/csas/PDF/2.\%20Dr.\%20Umbreen_ January-June\%202012.pdf

Jobe, R. (2003). Establishing cultural identity through picturebooks. In M. Styles \& E. Bearne (Eds.), Art, narrative and childhood (79-86). Sterling, VA: Trentham Books Ltd.

Johnston, I. (2010). Multicultural novels for the Canadian classroom. In M. C. Courtland \& T. J. Gambell (Eds.), Literature, media \& multiliteracies in adolescent language arts (133-152).

Vancouver, BC: Pacific Educational Press.

Khosla, C. R. (1980). A Canadian perspective on the Hindu woman: A study in identity transformation (Master's thesis). Retrieved from Open Dissertations and Theses at Retrieved from http://www.jstor.org/stable/3810013DigitalCommons@ McMaster. (Paper 5280).

Lindemann, Nelson, H. (1995). Resistance and insubordination, Hypatia, 10(2), 23-40. Retrieved from http://login.ezproxy.library.ualberta.ca/login?url=http://search.ebscohost.com/ login. aspx ?direct=true $\& d b=a 9 h \& A N=9506261257 \&$ site=ehost-live $\&$ scope $=$ site

Lugones, M. (1987). Playfulness, “world”-travelling, and loving perception, Hypatia, 2(2), 3-19. Retrieved from http://www.jstor.org/stable/3810013

Mehta, P. (2009). Identity negotiation: The perspective of Asian Indian women (Master's thesis). Retrieved from http://scholarcommons.usf.edu/etd/2100

Noddings, N. (2005). Caring in education. Retrieved from http://www.infed.org/biblio/ noddings_caring_in_education.htm

Orr, A. (2005). Stories to live by: Book conversations as spaces for attending to children's lives in school (Doctoral dissertation) Retrieved from Library and Archives Canada $=$ Bibliothèque et Archives Canada. 


\section{Lighting Diyas}

Ragoonaden, K. (2010). Creating identity and culture in the great white north. Citizenship, Social and Economics Education, 9(1), 14-22. Retrieved from http://dx.doi.org/10.2304/ csee.2010.9.1.14

Rosenblatt, L. M. (1994). The reader, the text, the poem: The Transactional Theory of the literary work. n.p.: Southern Illinois University Press.

Sarbin, T. R. (2004). The role of imagination in narrative construction. In C. Daiute \& C. Lightfoot (Eds.), Narrative analysis: Studying the development of individuals in society (pp. 5-20). Thousand Oaks, CA: Sage.

Shariff, F. (2008). The liminality of culture: Second generation South Asian Canadian identity and the potential for postcolonial texts. Journal of Teaching and Learning, 5(2), 67-80. Retrieved from http://ojs.uwindsor.ca/ojs/leddy/index.php/JTL/article/view/251/525

Statistics Canada. (2010). Projections of the diversity of the Canadian population. Retrieved from http://www.statcan.gc.ca/pub/91-551-x/91-551-x2010001-eng.pdf

Superle, M. (2011). Contemporary English-language Indian children's literature: Representations of nation, culture, and the new Indian girl. New York, NY: Routledge.

Vinz, R. (1997). Capturing a moving form: 'Becoming' as teachers. English Education, 29(2), 137-146. Retrieved from http://login.ezproxy.library.ualberta.ca/login?url= http://search.proquest.com/docview/214376816?accountid=14474

Wiltse, L. V. (2005). Cultural diversity discourse \& discourse practices in grade 9. Edmonton, AB: Qual Institute Press.

Yang, G. (2008). Graphic novels in the classroom. Language Arts, 85(3), 185-192. Retrieved from http://login.ezproxy.library.ualberta.ca/login?url=http://search.proquest.com/ docview/196906344/13B1B5EE072649AC0AD/4?accountid=14474 